\title{
What Factors Influencing Export Quantity for Indonesian and Philippine Coconut Oil
}

\author{
Rido Tanago ${ }^{1}$, David Kaluge ${ }^{2}$ \\ ${ }^{1}$ Doctoral Program in Economics, Brawijaya University, Indonesia \\ ${ }^{2}$ Faculty of Economics and Business Brawijaya University, Indonesia \\ Email: ridotanago@gmail.com, dkaluge@gmail.com
}

Received: October, 2018; Accepted: December, 2019; Published: December, 2019

Permalink/DOI: http://dx.doi.org/10.17977/um002v11i22019p186

\begin{abstract}
The coconut oil as main product of coconut is not competitive anymore compared to palm oil. Indonesia and Philippines are two top producers of coconut. This paper studies whether the price of coconut oil, the price of crude palm oil, the price of virgin olive oil, and gross domestic product influence the quantity export for Indonesian and Philippines coconut oil. Using multiple linear regression, the results indicate that in the Philippines the variables used in the study (price of coconut oil, price of crude palm oil, price of virgin olive oil and Philippines' GDP) have no significant impact on export quantity for Philippines. While coconut oil export quantity for Indonesia is significantly influenced by Indonesia's GDP.
\end{abstract}

Keywords: export of coconut oil, crude palm oil, virgin olive oil, gross domestic product

\section{INTRODUCTION}

Coconut (cocos nucifera, L.) belongs to the palmae or palm family, it is a tropical crop. It grows throughout the tropics and is widely called the "tree of life". Coconut is a multi- purpose plant, can be used to satisfy human needs. Especially for Indonesia, its fillet or meat is used for dessert or juice and coconut milk, its hard shell can be processed for carbon, its palm for building material and its leaves are used for the traditional party decoration. Coconut can be found in nearly every ceremonial or ritual activities in Indonesia. The major coconut products are: copra, coconut oil, copra meal and desiccated coconut. Recently there are other products of coconut that being consumed for health reasoning such as VCO (Virgin Coconut Oil) (Pinchumpholsang, 2010) and Coconut Water (Uwubanmwen et. al., 2011).

The coconut oil as main product of coconut is not competitive anymore compared to palm oil. By nature palm oil is more economical. Giant plantations have been growing palm in bulky and wide area. Now Indonesia is the biggest producer of palm oil in the world. The CPO (Crude Palm Oil) industry is expected to play a greater role in the international market for oils and fats (Obado et. al., 2009). As a substitute product of palm oil, the demand for coconut oil from year by year has been flatting. Except coconut oil and copra meal, other products of coconut have not been well developed such as desiccated coconut, coconut milk and VCO. In Thailand, VCO has increased from three at the beginning to more than 100 at present (Narong 2011). Around 95 percent of the desiccated coconut 
produced in Sri Lanka is exported (Jayalath and Weerahewa 2014). As long as the demand for coconut oil is not feasible so far, coconut growers have to diversify into these products.

Indonesia and Philippines are the two top producer countries of coconut. Philippines is the largest coconut producers in the world (Oniki, 1992). The followings are previous studies on domestic and export demand for coconut in Indonesia and Philippines products.

The focus of discussions in this section will be on the model, variable specification, interpretation and conclusions that are relevant to this study. Nyberg (1968) studied the Philippines coconut industry investigated the demand for lauric oils in the United States market and European market. To estimate the demand for lauric oils in the United States market, the quantity of lauric oils utilized in the United States is expressed as a function of the import price of lauric oils, income per capita and the quantity of soybean oil utilized. In the European demand function, the quantity of lauric oils utilized in Europe is expressed as a function of the import price of lauric oils, the income per capita, the quantity of soybean oil utilized and the quantity of groundnut oil utilized. Using the two-stage least squares technique, his findings indicated that for the United States demand, lauric oils was highly price inelastic at -0.24 . The income elasticity coefficient was +0.522 . The price and income elasticity coefficients of the United States demand equations were of the expected signs and were significant. The coefficients for the European demand equation indicated a price elasticity of -078 . Which was substantially less inelastic relative to the United States demand. The estimated income elasticity of +0.14 was not statistically significant. However, the positive sign was assumed to be correct, in the European market, ground-nut oil and soybean oil should be regarded as a substitute with regard to the lauric oils.

Baharsjah (1974), in his study of the domestic and international trade of Indonesian coconut products, formulated a simplified three equation model to estimate the export demand for Indonesian copra, the domestic demand for coconut oil and the export demand for Indonesian copra meal using ordinary least square and two-stage least square techniques.

He concluded that price elasticity of the export demand for Indonesian copra was estimated to be -0.6 or inelastic and income elasticity in importing countries showed a negative sign indicating that Indonesian copra had become an inferior good in the world market. The world exports of palm kernels and palm kernel oil had no significant impact on the exports of copra from Indonesia. Domestic demand for coconut oil was price elastic and the cross elasticity of demand with respect to the price of rice was negative. The coefficient with regard to population showed that expected positive sign. Price elasticity of the export demand for copra meal was estimated as -3.2 or quite elastic and the cross elasticity with respect to the price of groundnut meal was positive and large. Demand for copra in each of five regions of the world also was calculated. Palm kernel oil was found to be a substitute for copra in the EEC market and soybean oil a substitute in the United Kingdom and Scandinavian regions. Income elasticity for copra was negative in these three regions, but positive in Japan and the United States.

Laguna (1987) studied the Philippines' markets for coconut products, formulated four economic models for estimation and analysis the import demand 
by the United States, West Germany and the Netherlands for Philippines coconut products and by-product. The findings indicated the demands for coconut oil in the United States and West Germany were highly price inelastic. In the Netherlands, the demand was highly price elastic. The real income coefficients for the three countries included in this study were significant, with income elasticity greater than unity. Palm kernel oil appeared to be substitutes for coconut oil in West Germany, rapeseed and mustard seed oil were substitutes to coconut oil in the Netherlands. The study also indicated that a 1,000 metric ton increase in its domestic oilseed production would lead to a 248 metric ton decrease in imports of Philippines coconut oil into Netherlands and 8 to 10 metric ton decrease in West Germany's imports. Oilseed production in the United States could also contribute to the decrease in import of Philippines coconut oil. A 1,000 metric ton increase in the United States production of sunflower seed, soybean, linseed, groundnut and cottonseed would result in a 341 metric ton decrease in coconut oil imports. Price elasticities for copra are elastic in West Germany and the Netherlands. The income elasticities of copra import demand for both countries were highly elastic. The price elasticity coefficients for the Netherlands and West Germany's copra meal import demand were found to be positive and insignificant.

Kemala (1988) studied the agriculture, industry and trade of coconut and oil palm in Indonesia using linear programming. By simulating into three scenarios, he concluded that the optimal production of Indonesian coconuts in the year 2000 is 1,238,347 tons copra equivalent. Assuming there was no new plantings development, it would be an excess of production of 686,084 tons copra equivalent compared to the year 1985's production. This was due to inability of coconut oil to compete with palm oil. Coconut is only economically consumed as fresh food. Based on above information, this research will focus on variables that influence the demand for export coconut oil of Indonesia and Philippines because these two countries are the two top coconuts and coconut oil exporters.

Objective of the study is to analyze whether the price of coconut oil, the price of crude palm oil, the price of virgin olive oil, and gross domestic product influence the quantity export for Indonesian and Philippines coconut oil.

\section{METHOD}

The aim of the study is to examine whether coconut oil price, CPO price, virgin olive oil price, and GDP influencing coconut oil export quantity. Two big markets are chosen for this research: Indonesia and Philippines with justification that Philippines and Indonesia are the top two coconut oil producers. This research uses quantitative data. Data used is on year period of 1991 up to 2015. Data source is collected from the United States Department of Agriculture PSD database which is updated approximately once per month.

This research uses multiple linear regression: demand for Indonesia coconut oil export quantity and Philippines coconut oil export quantity as dependent variable. Price of coconut oil, price of crude palm oil, price of olive virgin oil, and GDP are independent variables. The model specification as follow.

The export quantity for Indonesia coconut oil:

$$
\text { IDQCO = } \mathrm{f}_{1}(\mathrm{PCO}, \mathrm{PCPO}, \mathrm{PVO}, \mathrm{IDGDP}, \mathrm{Z})
$$




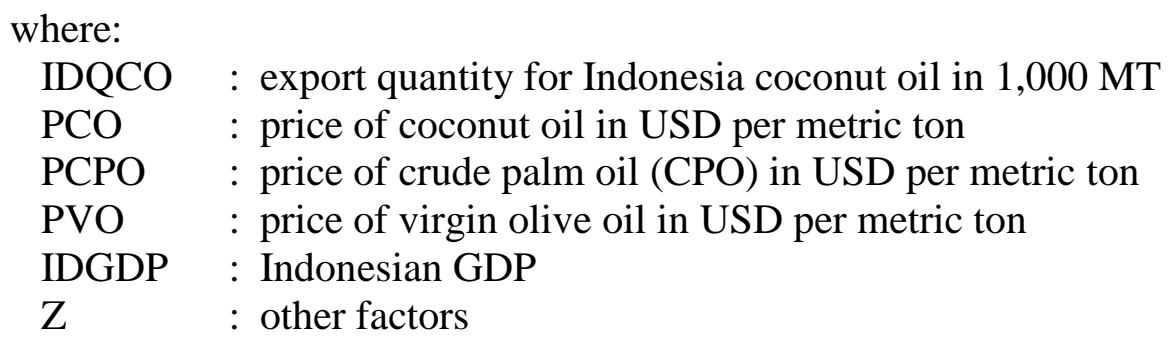

The export quantity for Philippines coconut oil:

$\mathrm{PHQCO}=\mathrm{f}_{1}(\mathrm{PCO}, \mathrm{PCPO}, \mathrm{PVO}, \mathrm{PHGDP}, \mathrm{Z})$

where:

PHQCO : export quantity for Philippines coconut oil in 1,000 MT

PCO : price of coconut oil in USD per metric ton

PCPO : price of crude palm oil (CPO) in USD per metric ton

PVO : price of virgin olive oil in USD per metric ton

PHGDP : Philippines' GDP

$\mathrm{Z} \quad$ : other factors

\section{RESULTS \& DISCUSSION}

Based on results using multiple linear regression analysis model of ordinary least square method (OLS), linear equations are obtained for each export quantity of Indonesia and Philippines coconut oil.

\section{Indonesia coconut oil export quantity}

The results of the multiple linear regression analysis on the factors that influence the export quantity for Indonesia coconut oil can be seen in table 1 . Coefficient of determination (R-squared) is 0,58 . It means that $58 \%$ variation in the export quantity for Indonesia coconut oil can be explained by the independent variables, while the rest is explained by other variables that are not included in the model. The analysis also shows that the value of the F-test has a probability of 0,001 . This value is much smaller than the value of the confidence level of $5 \%$. It shows that the independent variables: price of coconut oil, price of crude palm oil, price of virgin olive oil and Indonesia GDP simultaneously affect the export quantity of Indonesia coconut oil at the confidence level of $95 \%$.

Table 1. Results of Indonesia Coconut Oil Export Quantity

\begin{tabular}{ccccc}
\hline Variable & Coefficient & Std. Error & t-statistics & Prob. \\
\hline C & -95.900 & 151.461 & -0.633 & 0.533 \\
\hline PCO & 0.252 & 0.205 & 1.228 & 0.233 \\
\hline PCPO & -0.308 & 0.289 & -1.062 & 0.300 \\
\hline PVO & 0.030 & 0.029 & 1.017 & 0.321 \\
\hline IDGDP & 0.185 & 0.073 & 2.508 & $0.020^{*}$ \\
\hline
\end{tabular}

Note:

${ }^{*}=$ Significant at $95 \%$ confidence level 
The data generates following equation:

$I D Q C O=-95.90+0.252 P C O-0.308 P C P O+0.03 P V O+0.185 I D G D P$

From the linear equation, it can be seen that:

- If price of coconut oil increases $1 \%$, export quantity will increase $0.25 \%$ (insignificant).

- If price of CPO increases $1 \%$, export quantity will decrease $0.30 \%$ (insignificant).

- If price of virgin olive oil increases $1 \%$, export quantity will increase $0.03 \%$ (insignificant).

- If GDP increases $1 \%$, export quantity will increase $0.18 \%$ (significant).

Based on the classical assumption testing of multiple linear regression, Indonesia coconut oil export model passes all of 4 classical tests:

- Variance Inflation Factor: all independent variables are not multicollinearity

- Histogram - Normality Test: residual assumed normal distributed

- Serial Correlation LM Test: no auto-correlation in residual

- Heterokedasticity Test Glejser: no heterokedasticity in residual

\section{Philippines coconut oil export quantity}

The results of the multiple linear regression analysis on the factors that influence the export quantity for Philippines coconut oil can be seen in table 2 . Coefficient of determination ( $\mathrm{R}$-squared) is 0,11 . It means that $11 \%$ variation in the export quantity for Philippines coconut oil can be explained by the independent variables, while the rest is explained by other variables that are not included in the model. The analysis also shows that the value of the F-test has a probability of 0,653 . This value is much greater than the value of the confidence level of $5 \%$. It shows that the independent variables: price of coconut oil, price of crude palm oil, price of virgin olive oil and Philippines GDP has no significant impact on the export quantity of Philippines coconut oil at the confidence level $95 \%$.

Table 2. Results of Philippines Coconut Oil Export Quantity

\begin{tabular}{ccccc}
\hline Variable & Coefficient & Std. Error & t-statistics & Prob. \\
\hline C & 1187.044 & 300.364 & 3.952 & 0.001 \\
\hline PCO & -0.109 & 0.359 & -0.303 & 0.765 \\
\hline PCPO & -0.122 & 0.491 & -0.249 & 0.805 \\
\hline PVO & 0.001 & 0.050 & 0.026 & 0.979 \\
\hline PHGDP & -0.026 & 0.196 & -0.136 & 0.892 \\
\hline
\end{tabular}

The data generates following equation:

$$
P H Q C O=1187.044-0.11 P C O-0.12 P C P O+0.001 P V O-0.02 P H G D P
$$


From the linear equation, it can be seen that:

- If price of coconut oil increases $1 \%$, export quantity will decrease $0.10 \%$ (insignificant).

- If price of CPO increases $1 \%$, export quantity will decrease $0.12 \%$ (insignificant).

- If price of virgin olive oil increases $1 \%$, export quantity will increase $0.001 \%$ (insignificant).

- If GDP increases $1 \%$, export quantity will decrease $0.02 \%$ (insignificant).

Based on the classical assumption testing of multiple linear regression, Philippines coconut oil export model passes 3 of 4 classical tests:

- Variance Inflation Factor: all independent variables are not multicollinearity

- Histogram - Normality Test: residual assumed normal distributed

- Serial Correlation LM Test: there is auto-correlation in residual

- Heterokedasticity Test Glejser: no heterokedasticity in residual

From the above information, it indicates that virgin olive oil is a substitute product of coconut oil for both Indonesia and Philippines. It can be explained that virgin olive oil and virgin coconut oil (VCO) can be consumed interchangeable (Theerkhpathy et. al., 2014). While unlike previous study (Baharsjah, 1974; Laguna,1987), CPO and coconut oil are complementary products for both Indonesia and Philippines. It can be explained that in general cooking oil producers are mixing coconut oil with palm oil as cooking oil. Also coconut oil and palm oil can be used as materials for biodiesel. Significant bio-diesel demand determines price of palm oil (Applanaidu et.al., 2011).

\section{CONCLUSION}

The study is to examine whether coconut oil price, CPO price, virgin olive oil price, and GDP influencing coconut oil export quantity of Indonesia and Philippines. The study uses multiple linear regression model and assesses using four classical tests. Based on the results of the research, it is known that the export quantity for Indonesia coconut oil is significantly influenced by Indonesia GDP, and Indonesia coconut oil export model passes all of 4 classical tests. But in the Philippines, the variables used in the study (price of coconut oil, price of crude palm oil, price of virgin olive oil and GDP) have no significant impact on export quantity for Philippines coconut oil, and Philippines coconut oil export model passes 3 of 4 classical tests.

It can be concluded that virgin olive oil is a substitute product of coconut oil in both Indonesia and Philippines. Palm oil is a complimentary product of coconut oil in both Indonesia and Philippines. GDP influences export quantity of Indonesian coconut oil but insignificantly influences export quantity of Philippine coconut oil. Coconut oil had to compete with other low price vegetable oils and fats in the international market. 


\section{REFERENCES}

Applanaidu, S. D., Arshad, F. M., Shamsudin, M. N., Hameed, A. A. A. (2011). An Econometric Analysis of the Link between Biodiesel Demand and Malaysian Palm Oil Market. International Journal of Business and Management, 6(2), 35-45.

Baharsjah, S. (1974). The Domestic and International Trade of Indonesian Coconut Products, Unpublished Ph.D. Dissertation, North Carolina State University, North Carolina, USA.

Chomchalow, N. (2011). Health and Economic Benefits of Coconut Oil Production Development in Thailand. AU J.T., 14(3), 181-187.

Jayalath, K.V.N.N, Weerahewa, J. (2014). Tariff Endogeneity: Effects of Export Price of Desiccated Coconuts on Edible Oil Market in Sri Lanka, Tropical Agricultural Research, 25(4), 476-486.

Kemala, S. (1988). Pola Pertanian, Industri, Perdagangan Kelapa dan Kelapa Sawit di Indonesia [Agricultural, Industrial, Trading Pattern of Coconut and Oil Palm in Indonesia] (Doctoral Dissertation). Institut Pertanian Bogor, Indonesia.

Laguna, R. S. (1987). An Econometric Analysis of the Philippines' Markets for Coconut Products, Unpublished Ph.D. Dissertation, Oklahoma State University, Oklahoma, USA.

Nyberg, A. J. (1968). The Philippine Coconut Industry, Unpublished Ph.D. Dissertation, Cornell University, New York, USA.

Obado, J., Syaukat, Y. Siregar, H. (2009). The Impacts of Export Tax Policy on The Indonesian Crude Palm Oil Industry. J. ISSAAS. 15(2), 107-119.

Oniki, S. (1992). Philippine Coconut Industry and The International Trade (Master's thesis). Department of Agricultural Economics, Michigan State University, Michigan, USA.

Pinchumpholsang, W. (2010). Cost-Benefit Analysis of Coconut Oil as Cash Crop: A Case Study of Prachuap Khiri Khun Province. RMUTP Research Journal Special Issue, The $4^{\text {th }}$ Rajamangala University of Technology International Conference, 443-454.

Theerkhpathy, S., Chandrakumarmangalam, S. (2014). Coconut Processing Industries: An Outlook, Global Journal of Commerce \& Management Perspective, 3(5), 219-221

Uwubanmwen, I. O., Nwawe, C. N., Okere, R. A., Dada, M., Esegbe, E. (2011). Harnessing the Potentials of the Coconut Palm in the Nigerian Economy, World Journal of Agricultural Sciences, 7(6), 684-691. 